\title{
Organizational ergonomics of occupational health methods and processes in a Brazilian oil refinery
}

\author{
Lucy M. S. Bau ${ }^{\text {a,b* }}$, Jean P. Farias ${ }^{\text {a,c }}$, Sandro A. Buso ${ }^{\text {a, }}$ Carolina R. Marcon Passero ${ }^{a, b}$ \\ ${ }^{a}$ Petrobras, Petróleo Brasileiro S.A. Refinaria Presidente Getúlio Vargas. Rod. do Xisto BR 476, km 16, CEP \\ 83707.440 - Araucária - PR - Brazil. \\ ${ }^{b}$ Fisiotrab Ergonomia, Saúde e Segurança no Trabalho Ltda. Av. Getúlio Vargas, 2932, Conj 406, CEP \\ 80240.040 - Curitiba - PR - Brazil. \\ ${ }^{c}$ Qualimaster Consultoria Empresarial Ltda. Rua Marechal Deodoro, 869 Conj 203, CEP 80060.010. Curitiba- \\ PR - Brazil.
}

\begin{abstract}
Organizational ergonomics refers to the optimization of social technical systems, including their organizational structures, policies and processes. The relevant topics include communications, management of resources, work projects, temporal organization of work, team work, participative project, new work paradigms, cooperative work, organizational culture, network organizations and quality management (IEA, 2000). The purpose of this study was the reorganization of the methods and processes of the occupational health sector (SMS/SO - Portuguese acronym of the area) of a petrochemical company. The work involved thirty professionals: a coordinator, two occupational physicians, one cardiologist, one occupational dentist, two occupational nurses, eleven occupational health technicians, one social worker, one nutritionist, one phonoaudiologist, one ophthalmologist, one biochemist, two ergonomists, three administrative assistants, one administrator and one psychologist, during a six-month period. The methodology that was used sought to establish a cooperative alliance focused on change, transformation and acquisition of skills, reflecting directly on the attitudes and performance of the leaderships and their work teams. In addition to the feedback practice, the following supporting tools were used for the study's success: "Functional Polyvalence Matrix", "Management of Failures", 5W2H", "6M", "5 Why" and "process mapping". The intended results after the organization ergonomics restructuring process will allow the leader to help his or her team to make a diagnosis of the problems, identify options, develop strategies, establish targets and action plans, remove barriers, review contexts and implement the business management fundaments: planning, organization, management, coordination and control. The transformation possibilities allow us to consider some hypothesis: Before: Focus only on results. After: Engage collaborators to create sustainable results. Before: Operating profile. After: Tactical/strategic profile. Before: Find errors. After: Value effort and development. Before: Listen to what is being said. After: Understand what is being said. Before: Create fears of the consequences. After: Create room for risk. Before: Be the one who approves and decides. After: Be the cooperative support.
\end{abstract}

Keywords: reliability, health management, user satisfaction, leadership.

*Corresponding author. E-mail: lucymarabau.fisiotrab@petrobras.com.br 


\section{Introduction}

Organizational ergonomics refers to the optimization of social technical systems, including their organizational structures, policies and processes. The relevant issues include communications, management of resources, labor projects, temporal work organization, teamwork, participative project, new work paradigms, cooperative work, organizational culture, network organizations and quality management [1]

The field of organizational ergonomics is built upon an obvious observation that all working activity takes place within the sphere of an organization. This field experienced an excellent development, known internationally as ODAM - Organizational Design and Management - representing to some people a synonym of macro ergonomics.

Ergonomics aims at modifying working systems to suit the activities existing therein with the capabilities, skills and limitations of individuals, aiming at an efficient, comfortable and safe performance [2].

The uses that ergonomics can bring to the sphere of organizations are based on the known determination of physical technology on work organization and labor conditions, which are elements that will determine the equation of the company's results. According to Vidal [3], the largest uses of ergonomics in the organizational field have been:

- Modeling of processes for preparing scenarios and scripts for organizational changes;

- Analysis of the requirements of new organizational projects in terms of skills, limitations and remaining features, specifying training needs and new capabilities;

- Construction of implementation schedules to prevent disinvestment or lack of use of knowhow existing particularly at the operating level;

- Expertise and prevention of accidents.

According to NR - 17 [4], “(...) the organization of work should be adequate to the psycho-physiological features of workers and to the nature of the work to be carried out". The organization of work for the purpose of that NR should take into account at least the following items:

- Objectives and targets;

- Mapping of production processes;

- Management of operating failures;

- Leadership development;

- Task content; and
- Feedback

The purpose of this study was the reorganization of the working methods and processes in the occupational health area (SMS/SO) of a petrochemical company.

\section{Materials and methods}

The methodology used was descriptive, seeking to reconcile the use of quality tools, such as "process mapping" and "failure management", redirecting the previously established management by activity to management by processes, ratifying Ribeiro [5], who senses that one of the objectives of organizational ergonomics is the optimization of social-technical systems, including their organizational structures, corporate policies, production processes and business. The study was carried out in an oil refinery and involved all professionals working in the occupational health clinic (SNS/SO Portuguese acronym of the area), comprising a total of thirty professionals, some being employees of the company and others outsourced professionals. They included a coordinator, two occupational physicians, one cardiologist, one occupational dentist, two occupational nurses, eleven occupational health technicians, one social worker, one nutritionist, one phonoaudiologist, one ophthalmologist, one biochemist, two ergonomists, three administrative assistants, one administrator and one psychologist. Work was divided into four shifts: an administrative shift, which concentrated most professionals, and 3 alternating shifts, as follows: shift "A" from 7:30 am to $3: 30 \mathrm{pm}$, "B" from $3: 30 \mathrm{pm}$ to $11: 30 \mathrm{pm}$ and " $\mathrm{C}$ " from 11:30 pm to 7:30 am.

The following support tools were used: "Functional Polyvalence Matrix", "Management of Failures", 5W2H", "6M", "5 Why" and "process mapping". The study was carried out over a 6 month period from the diagnosis, intervention to the reassessment.

According to the NBR ISO 9001:2008 [6], the determination of the essential processes, as well as appropriate forms of monitoring and measurement must be in place. In this respect, the processes were duly mapped and presented to the collaborators. The methodology used in the process mapping was the one suggested by Maranhão [7], which encompasses eight stages, as follows: $1^{\text {st }}$ stage: definition of the 
process leadership; $2^{\text {nd }}$ stage: determination of the process objectives; $3^{\text {rd }}$ stage: identification of the entries; $4^{\text {th }}$ stage: identification of the outputs and interactions; $5^{\text {th }}$ stage: identification of controls; $6^{\text {th }}$ stage: determination of activities; $7^{\text {th }}$ stage: definition of the monitoring and $8^{\text {th }}$ stage: establishment of performance indicators.

The discussion of results with the involved parties contemplated the use of feedback, the basic assumption of which is to promote the ongoing improvement of processes and services through feedbacks of suggestions and complaints from the interested parties, such as customers, employees, stockholders, public entities and the community as a whole [8].

\section{Presentation and discussion of results}

Initially, a diagnosis was made. The diagnosis indicated an analyst behavior of the management, a typical form of management of small companies, which is centralization, caution in taking decisions and a vision from the inside to the outside, i.e., the cognitive style of the manager is a determining factor in the form he or she sees and surveys the market, and how he or she takes strategic decisions [9]. In this respect, it was observed that more precise management information on operating failures was missing, opening room for the implementation of the "management of failures" tool. According to the NBR ISO 9001:2008, products/services that are not according to the original specifications are considered non-conforming products/services. A form of control was established, as well as the statistical recording of the incidence of such failures during a 60-day period, aiming at improving the operating processes.

The process mapping was made and the following process performance indicators were established, as per table 1:

Table 1

Performance indicators by process.

\begin{tabular}{|c|c|}
\hline PROCESS & INDICADOR \\
\hline Occupational nursing & $\begin{array}{l}\text { - \% Legal conformity attendance - SMS/net; } \\
\text { - \% Effectiveness of health and epidemiological } \\
\text { events; } \\
\text { - \% Effectiveness of campaigns; } \\
\text { - Training/Hour/men; } \\
\text { - \% Customer satisfaction. }\end{array}$ \\
\hline Medical coordination & $\begin{array}{l}\text { - ASO; EFA; PEREMP; PTP; RC; TFDC; TFDCC; } \\
\text { TIDO; TTAP. }\end{array}$ \\
\hline $\begin{array}{c}\text { Technical and } \\
\text { administrative support } \\
\text { and attendance }\end{array}$ & $\begin{array}{l}\text { - Punctuality in delivering notes; } \\
\text { - \% Customer satisfaction. }\end{array}$ \\
\hline \multirow{5}{*}{$\begin{array}{l}\text { Technical health } \\
\text { services }\end{array}$} & $\begin{array}{l}-\% \text { finalization of issue processes and control of } \\
\text { NOC and CAT on time; }\end{array}$ \\
\hline & - \% Compliance with the EMO carrying out schedule; \\
\hline & - BAD; \\
\hline & - \% Internal satisfaction; \\
\hline & - \% Customer satisfaction. \\
\hline
\end{tabular}

After the process mapping, the failures were raised. Amongst 25 identified potential failure types, the most registered ones during the review period referred to "data migration". Some considerations for discussion are:

- The most visible failure resides in the migration of data (88\%). However, the correction of such failures depends on outsourced collaborators;
- Another analysis point is that, excluding data migration, only $3 \%$ of the failures required rework;

- It is possible to say that a large part of the failures take place in the " $\mathrm{C}$ " shift, regardless of demand;

- There is no leadership present in the " $C$ " shift. It is possible that the "C" shift failures could 
be lower, if a leadership was present, but this hypothesis must be tested.

For the indicated failures, the tool $5 \mathrm{~W} 2 \mathrm{H}$ was set up to prepare a corrective action plan. This tool consisted basically of making questions to obtain essential information that will help support overall planning. The 5W2H terminology, according to Seleme \& Stadler [10] stands for What, Who, Why, Where, When, How, How Much/How Many. This tool can be applied to several areas of knowledge, serving as a planning base, such as, for example, for:

- Quality Planning - Identifying the relevant quality standards for the project and determining how to meet them, involving considerations of when, how, how much/how many and where to act.

- Planning of Purchases - Identifying the project needs that can be better met by purchasing products and services outside the organization, involving the considerations of when, how, what, how much/how many and where to buy.

- Planning of Human Resources - Identifying the project needs that can be better met by using the Human Resources available within the organization or considerations of when, how, who, how many and where to hire.

- Planning of Risks - Identifying the risks to be considered, when to implement a contingency action and how much to make available to mitigate or transfer risks.

On analyzing the failures, the capabilities of the involved collaborators were checked in terms of their mastery of the activities required by the work processes. This analysis pointed to an average polyvalence of $59 \%$ of the team of ten collaborators, with the following distribution: one collaborator with $25 \%$, three collaborators with $45 \%$, one with $50 \%$, two with $55 \%$, one with $72 \%$ and two with $100 \%$ polyvalence in their activities.

According to Figure 1, in June 2011, 405 attendances were made and 154 failures were observed, $88 \%$ of which resulting from the lack of data migration and 147 generating rework.

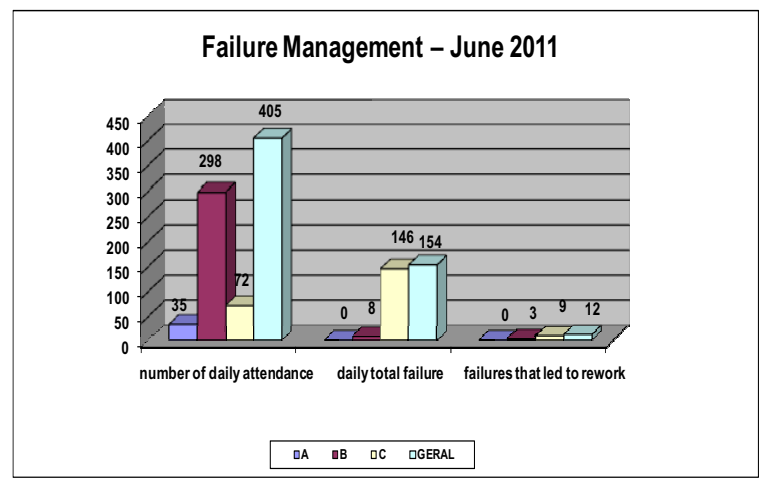

Figure 1 - Failure management in the month of June 2011

In the month of July 2011, 392 attendances were made and 147 failures were observed, $80 \%$ of which due to the lack of data migration. The failures requiring additional work declined to 46 , as shown in Figure 2 below.

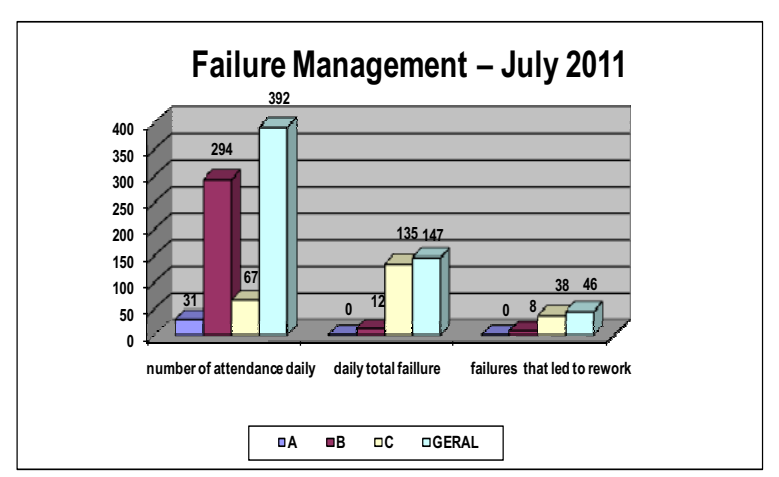

Figure 2 - Failure management in the month of July 2011

In the months of both, June and of July, it was possible to see that the largest number of failures occurred in the "C" shift (from 11:30 pm to 7:30 am).

Of July's 147 failures, 93 were due to the lack of data migration and 23 due to lack of exam migrations (Figurer 3). 


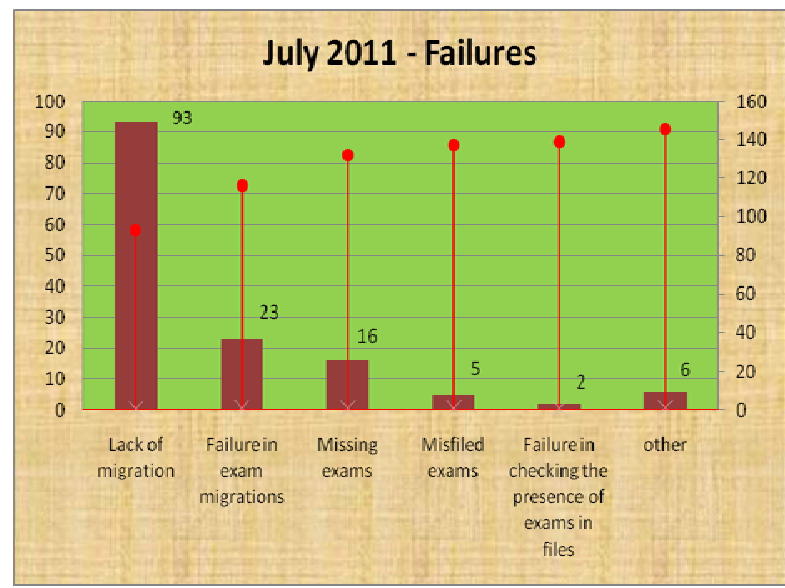

Figure 3 - Pareto chart of the failures in the month of July 2011

In the feed back stage, meetings were held involving the operating interfaces with the leaderships to discuss the results. The results obtained initially, considering just two months of the implementation of the methodology, already point to improvements in the SMS/SO area of the refinery being analyzed, influencing the following points:

- On the decline in the PTP indicator: PTP = percentage of work loss due to illness of accident in the refinery, with a $1.94 \%$ target;

- On the Ergonomics Action Plan;

- On the Ambience Survey;

- On the performance management (GD);

- On the targets;

- On the Feedback enhancement;

- On the SGCA's.PDI.

\section{Conclusion}

The most visible failure lies on the lack of data migration ( $88 \%$ in June and $80 \%$ in July), this work depending on outsourced collaborators. There was nonetheless a substantial decline of 8 percentage points from June to July. Without taking into account data migration, only $3 \%$ of the failures required rework in June, against $11.7 \%$ in July. This may also mean that the data is being better registered, showing increased reliability in the tool. It is possible to say that a large number of the failures took place in the "C" shift, regardless of demand and of the analyzed period. It is possible that the " $\mathrm{C}$ " shift failures could be lower if a leadership was present, but this hypothesis must be tested. Another hypothesis that is being tested is that the practice of feedback may improve results in the continuity of the implemented actions, with an influence on compliance.

The objectives of this study were reached with respect to the larger receptivity of the health team in reorganizing their work processes and methods, and in the indicators that showed a decline in the failures and in the rework needs, ratifying the effectiveness of the management tools that were used. However, this social-technical study has to continue its investigation, given the complexity of the approached issues. The continuous practice of feed-back associated with a periodical organization climate survey may confirm the impact of the achieved improvements in the organizational culture.

\section{References}

[1] IEA, 2000, available at http://www.iea.cc/01_what/What $\%$ 20is\%20Ergonomics.html, accessed on: 08/08/11.

[2] ABERGO, 2000 - A certificação do ergonomista brasileiro Boletim 1/2000 Editorial, Associação Brasileira de Ergonomia.

[3] Vidal, M.C. A Materialidade da Organização do Trabalho como objeto da Intervenção Ergonômica p. 89-138. In JFS Filho \& S Jardim (orgs.) (1997).

[4] Labor and Employment Ministry, Order nr 3.214/78, of the Occupational Safety and Health Secretariat, NR 17 Ergonomia.

[5] Ribeiro A.R.B; Silva D.E.P; Medeiros D.D; A Influência da Ergonomia Organizacional na Motivação dos Funcionários da Área de Saúde. XXV National Meeting of Production Eng. Porto Alegre, RS, Brasil, Oct 29 to Nov 01, 2005. ENEGEP 2005 ABEPRO 2408. Available at http://www.abepro.org.br/biblioteca/ENEGEP2005_Enegep04 04 1054.pdf, accessed on 08/08/11.

[6] ABNT NBR ISO 9001:2008, Sistemas de gestão da qualidade - Requisitos.

[7] Maranhão, M. ISO SérieE 9000 - Manual de Implementação Versão 2008 - 9a Edição - 2011. Qualitymark.

[8] Farias, J.P.; Rhoden, V. N.; Souza, T.M.; Canciglieri Junior O.. Formação e classificação da estratégia em movelarias de Curitiba: um estudo comparativo de 127 casos. in: XVI SIMPOSIUM OF PRODUCTION ENGINEERING - SIMPEP 2009, Bauru. UNESP. Available at http://www.simpep.feb.unesp.br/, accessed on: 08/08/11.

[9] Farias, J.P. Proposta de um modelo para avaliação das práticas do ecodesign na indústria moveleira : um estudo de caso / Thesis (máster degree) - Pontifícia Universidade Católica do Paraná, Curitiba, 2009.

[10] Seleme, Robson; Stadler, Humberto. Controle da Qualidade: As ferramentas essenciais. Curitiba: IBPEX, 2008. 